\title{
Innovative Forms of Sustainable Development of the Heat Supply Industry
}

\author{
Fomenko N.M.* \\ Doctor of Economics, Professor, Department of \\ Management and Innovation, \\ National Research Moscow State University of Civil \\ Engineering, \\ fnata77@mail.ru
}

\author{
Maksimova D.A. \\ Lecturer, Department of Management and Innovation, \\ National Research Moscow State University of Civil \\ Engineering, \\ kosti4eva.daria@yandex.ru
}

\begin{abstract}
The article substantiates the need to create a cluster space for the heat supply industry. The analysis identified a large degree of deterioration of fixed assets and the beginning of decentralization of the heat supply industry. The conclusion about the need to transform the management structure of the industry was drawn. As a solution to this problem, a new innovative cluster form has been proposed. It can improve productivity of the industry as a whole and individual enterprises in particular.
\end{abstract}

Keywords - innovation, sustainable development, innovation cluster, united heat supply organization, virtual organization, cluster participants.

\section{INTRODUCTION}

In recent decades, clusters became one of the forms of innovative sustainable development policy. Globalization of processes of functioning of enterprises turns into cooperation in its highest collaborative forms, when actions of all participants in the production process are combined, ensuring synergy of collective efforts [1].

Geographical proximity which is the basic factor in the formation of the cluster structure is in the background of the modern innovative environment of sustainable development. In such conditions, clusters and their participants play the leading role in effective management structures of industrial enterprises pursuing common goals.

In modern conditions, the heat supply industry is characterized by a high level of monopolization. The high level of monopolization of the Russian economy is due to enterprises that were created in the Soviet period. Federal Law No. 147-FZ of 08.17.1995 on Natural Monopolies defines this concept as a market condition when there are no goods (products / services), there are no competitors due to technological features of the production of goods (products / services) that cannot be replaced by substitutes [2]. The demand for goods (products / services) manufactured by natural monopolies depends on changes in the price of goods (product / service). However, in the Russian legislation, the characteristics of natural monopolies are clearly defined and unambiguously manifested in the heat supply industry: high efficiency in satisfying the demand for thermal energy, thermal power; the lack of competitive environment; the specifics of the thermal energy production and transportation; reduction of production costs per unit of generated heat energy, heat capacity along with an increasing volume of heat energy production, heat capacity; the lack of substitutes for products (thermal energy) of natural monopolies; inelastic demand for thermal energy due to the low dependence of consumer demand for thermal energy on its price.

The sectors of the Fuel and Energy Complex (FEC) are characterized by a high level of capital intensity, long payback periods, a long technological production cycle of thermal energy generation, hard access to resources, etc. The characteristics described above are caused by severe market barriers, and all of them are associated with a high level of investment.

Thus, in the heat supply industry, unified heat supply organizations transport heat energy within the territorial boundaries set by the heat supply scheme. In such conditions, the economies of scale are clearly manifested. As a result, the monopolists expand their influence, dominate regional (national) markets and implement price discrimination policies. The authors identified key functions of natural monopolies in the heat supply industry:

1. Infrastructure function. Natural monopolies have special infrastructural functions: main networks for transporting heat (power) to consumers, operation of main networks, market conditions (availability of unified heat supply organizations, heat supply organizations, etc.) and coordination of supply and demand.

2. Social function. Products produced by natural monopolies are life-supporting and play a huge role in consumption. A priori, providing consumers with thermal energy (coolant), maintaining thermal power in buildings, it focuses on the life support of the consumer.

3. Built-in stabilizers. Two options are possible. The production of natural monopolies positively interacts with social production in the long run. But in the short run, they can play a countercyclical role during economic downturns and booms due to the stable consumer demand for their products. Natural monopolies are more sustainable because less susceptible to obsolescence of fixed capital.

4. Fiscal function. Natural monopolies operating in the energy and raw material sectors are large taxpayers, as they produce a significant amount of products and export them. 
5. Cost-generating function. The costs of production of natural monopolies make up a significant part in the structure of their costs. However, the lack of modern technologies increases costs and prices. It is no accident that a decrease in energy intensity, an increase in energy saving, and optimization of heat supply costs are reflected as development directions in Program 2020.

However, as the Russian and foreign activities of heat supply organizations show, the monopoly is not efficient and is in a deplorable state. Experts say that the industry is in a deep crisis, which can lead to the collapse of the communal system. At the same time, there is no official access to official statistics on accidents in the autumn-winter period starting in
2018. The Ministry of Energy and the Ministry of Construction supervise the heat supply sector, but do not disclose data on this one of the most important sectors of housing and communal services in public sources [3].

In 2005-2016, the total capacity has a general tendency to decrease by $6 \%$ in total and by $8 \%$ in urban settlements. The average heating capacity decreased by $16.7 \%$ - from $9.6 \mathrm{Gcal} /$ $\mathrm{h}$ to $8.0 \mathrm{Gcal} / \mathrm{h}$ in 2016 . In urban areas, this decrease was $2.4 \%$ - from $16.8 \mathrm{Gcal} / \mathrm{h}$ to $16.4 \mathrm{Gcal} / \mathrm{h}$. In rural areas, it was $28 \%$ - from $2.5 \mathrm{Gcal} / \mathrm{h}$ to $1.8 \mathrm{Gcal} / \mathrm{h}$. In 2012-2016, the heat capacity of public thermal power plants decreased by 43.3 thousand Gcal / h. The total capacity of boiler houses increased by 13.1 thousand Gcal / h.

TABLE I. THE STRUCTURE OF THERMAL ENERGY PRODUCTION BY FEDERAL DISTRICTS AND TYPES OF SOURCES FOR 2013-2017, MLN GCAL.

\begin{tabular}{|c|c|c|c|c|c|c|c|c|c|c|c|c|}
\hline Source & Year & Total & $\begin{array}{c}\text { Imbalance } \\
\text { between } \\
\text { the RF } \\
\text { and the } \\
\text { FD }\end{array}$ & CFD & NWFD & SFD & NCFD & CFD & UFD & SFD & FEFD & KFD \\
\hline \multirow{5}{*}{$\begin{array}{c}\text { Heat } \\
\text { production, } \\
\text { total }\end{array}$} & 2013 & 1292,9 & 85,4 & 317,1 & 163,7 & 38,5 & 9,2 & 264,2 & 141,2 & 208,6 & 65,1 & - \\
\hline & 2014 & 1322,3 & 82,0 & 319,4 & 162,2 & 39,7 & 9,4 & 285,6 & 145,0 & 211,9 & 64,7 & 2,4 \\
\hline & 2015 & 1243,9 & 51,0 & 300,3 & 157,1 & 35,7 & 9,2 & 278,4 & 136,9 & 209,5 & 65,0 & 0,9 \\
\hline & 2016 & 1269,0 & 0,1 & 329,9 & 163,0 & 39,5 & 9,4 & 296,1 & 139,9 & 225,3 & 65,7 & \\
\hline & 2017 & 1258,0 & $-4,6$ & 320,3 & 163,4 & 38,9 & 10,8 & 297,5 & 139,6 & 224,5 & 67,6 & \\
\hline \multirow{5}{*}{$\begin{array}{l}20 \mathrm{G} \mathrm{cal} \\
\text { boiler } \\
\text { rooms }\end{array}$} & 2013 & 627,4 & - & 193,3 & 92,5 & 22,5 & 6,1 & 113,7 & 68,5 & 90,4 & 37,7 & \\
\hline & 2014 & 639,2 & - & 193,3 & 88,4 & 22,9 & 6,1 & 125,1 & 69,8 & 94,0 & 37,6 & 1,9 \\
\hline & 2015 & 625,2 & - & 183,7 & 86,4 & 20,3 & 6,3 & 127,0 & 66,2 & 96,0 & 37,3 & 0,3 \\
\hline & 2016 & 674,4 & - & 202,2 & 89,9 & 22,2 & 6,2 & 141,4 & 68,1 & 107,6 & 36,8 & \\
\hline & 2017 & 668,5 & - & 196,5 & 90,6 & 21,1 & 7,6 & 140,5 & 66,9 & 105,2 & 40,1 & \\
\hline \multirow{5}{*}{$\begin{array}{l}\text { Other } \\
\text { sources } \\
\text { (electric } \\
\text { boiler) }\end{array}$} & 2013 & 3,3 & - & 0,1 & 0,5 & 0,0 & 0,0 & 0,1 & 0,0 & 1.8 & 0,8 & \\
\hline & 2014 & 3,1 & - & 0,1 & 0,5 & 0,0 & 0,0 & 0,1 & 0,0 & 1.6 & 0,8 & 0,0 \\
\hline & 2015 & 2,6 & - & 0,1 & 0,4 & 0,0 & 0,0 & 0,1 & 0,1 & 1.2 & 0,7 & 0,0 \\
\hline & 2016 & 2,6 & - & 0,1 & 0,3 & 0,0 & 0,0 & 0,1 & 0,1 & 1.2 & 0,8 & - \\
\hline & 2017 & 2,5 & - & 0,1 & 0,3 & 0,0 & 0,0 & 0,1 & 0,1 & 1.0 & 0,9 & - \\
\hline
\end{tabular}

In the total capacity of public heat supply sources, the share of heating boilers was $67.9 \%$ for $2012-2016$, the share of thermal power plants was $32.1 \%$. The structure of heat supply sources is presented in Table 1.
The changes are due to the depreciation of equipment, heat losses, low efficiency of heat sources aggravated by the decentralization [4]. To improve the efficiency, ensure sustainable development and attract investment in order to modernize fixed assets, it is necessary to implement an innovative form of the heat supply process. It can be a 
collaboration of participants in the thermal energy market, ensuring the development of information systems and mechanisms, in particular, an innovative cluster association, providing sphere-industry development.

Development of the cluster theory, specific problems of cluster development, their advantages and organization specifics are associated with M. Porter, M. Enright, E. Feather, E. Bergman and others. Among the Russian researchers one can mention Kutsenko E.S., Gokhberg L.M., Smorodinskaya N.V., Abashkin V.L. et al. [1.4-11].

\section{RESULTS AND DISCUSSION}

An analysis of publications showed that from an economic point of view, the heat supply cluster is a group of complementing participants in regional organizations generating and transporting thermal energy. The goal of creating a heat supply cluster is the formation of a heat supply infrastructure aimed at the innovative development of cluster territories, cooperation and investing. The use of an innovative cluster is aimed at attracting additional investment and uniting heat supply enterprises within the network organization in order to achieve the most complete and high-quality customer satisfaction. Thus, the new innovative form of relations will allow for combining institutional, evolutionary and reproductive approaches, which can strengthen the synergistic effect of multi-dimensional subjects of the innovation cycle, reproduction and commercialization of innovations. Among the key principles of these entities, one can mention distribution, reliability and multicore principles.

The innovative form of a cluster should cover several activities - subclusters. The approximate composition of the cluster members is presented in Table 2.

TABLE II.

LIST OF PARTICIPANTS IN THE HEAT SUPPLY CLUSTER

\begin{tabular}{|c|c|}
\hline Participants & Features \\
\hline $\begin{array}{c}\text { Heat transport organizations } \\
\text { (owners of main networks) }\end{array}$ & Form a governing body. \\
\hline Heating network organization & may members of the cluster \\
\hline $\begin{array}{c}\text { Heat supply organizations: } \\
\text { United heat supply organizations }\end{array}$ & $\begin{array}{c}\text { Morm a governing bompanies. May be } \\
\text { represented by virtual } \\
\text { organizations. }\end{array}$ \\
\hline $\begin{array}{c}\text { Wholesale resellers of thermal energy } \\
\text { (distributing thermal energy and } \\
\text { operating heating networks) }\end{array}$ & may be members of the cluster \\
\hline $\begin{array}{c}\text { Organizations operating local heating } \\
\text { systems and collecting payments }\end{array}$ & may be members of the cluster \\
\hline $\begin{array}{c}\text { Heat sales and heat service } \\
\text { organizations }\end{array}$ & Form a governing body. \\
\hline Educational institutions & may be members of the cluster \\
\hline $\begin{array}{c}\text { Technological and industrial } \\
\text { infrastructure }\end{array}$ & may be members of the cluster \\
\hline
\end{tabular}

A management company heads the innovative form. It can be any cluster member. In our opinion, this function should be assigned to heating companies. Structural units of the management system and enterprises providing various heat supply and repair services may have territorial disunity. An integrated information and communication system allows for joint activities within the management company on the basis of network interaction. At the same time, structural units of the cluster and enterprises providing services can be created in the form of distributed virtual organizations [12]. Obligatory conditions for the existence of a cluster are an educational component that can ensure the development of engineering and technology, as well as training of specialists. All subclusters are independent units and can participate in other innovative formations. A cluster can increase the innovative potential of the industry, region and individual enterprises.

The role of the virtual heat supply organization in the cluster is debatable. Any heat supply organization sells energy to consumers and (or) heat supply organizations and owns heat sources and (or) heat networks in the heat supply system through which heat is supplied to consumers. However, for the heat supply cluster, these functions are not sufficient. It becomes necessary to introduce a virtual heat supply organization into the heat supply cluster. The management system of the virtual heat supply organization will act as a legislative center establishing interaction rules in the cluster and transport heat energy, produce heat energy (power) and ensure conditions for the functioning of heat sources and (or) heat networks in the heat supply system. It will include separate substructures that implement alternative options for production processes and (or) the provision of thermal energy (power).

\section{CONCLUSION}

Thus, the use of an innovative form in the heat supply industry will

1. allow participants of the innovative cluster association to rely on their capabilities and perform individual functions, strengthening the organization system.

2. improve the efficiency of the organization by focusing on certain functions.

3 . reduce heat supply costs.

4. attract additional investment for the development of production and material resources, as well as for the implementation of innovations.

5. improve the information flow between the participants in the innovation cluster.

6. improve quality of services and ensure a full production cycle.

Cluster mechanisms can consolidate united efforts of the heat supply cluster participants aiming at efficient generation and transportation of heat energy, form new areas: production of high-tech heating equipment, production and implementation of innovative technologies to minimize heat loss, maintain temperature conditions, produce measuring sensors and other innovative devices. The generalization of studies made it possible to present the structure and content of the innovative cluster approach in heat supply, including activities of subclusters, as well as a virtual heat supply organization. 


\section{References}

[1] N. V. Smorodinskaya, D. D. Katukov, "Innovation Ecosystems vs. Innovation Systems in Terms of Collaboration and Co-creation of Value", Proceedings of the 50th Hawaii International Conference on System Sciences, pp. 5245-5254, January 2017 (HICSS-50, 2017Д.

[2] Federal Law No. 147-FZ of August 17, 1995 "On Natural Monopolies": adopted by the State Duma on August 19, 1995. Published in "Collection of Legislation of the Russian Federation”, No. 34, art. 3426, 1995.

[3] Publication "Heat without a host: accidents are occurring, reform in Russia is stalling." from: https://ria.ru/20190218/1551047795.html (2019).

[4] N. Verstina, E. Evseev, "Technical-and-economic aspects of the analysis of the heating systems maintenance in the conditions of urban environment", MATEC Web of Conferences, vol. 106, 08090, November 2016 (SPbWOSCE-2016 "SMART City", 2017)

[5] M. E. Porter, C.H.M. Ketels, "Clusters and Industrial Districts: Common Roots, Different Perspectives", A Handbook of Industrial Districts, 2009.
[6] M. J. Enright, Regional clusters and economic development: a research agenda, 1996.

[7] E. J. Feser, Clusters and Regional Specialisation. London: Pion, pp. 1840, 1998.

[8] E. M. Bergman, E. J. Feser, Industrial and Regional Clusters: Concepts and Comparative Applications. Regionl Research Institute, WVU, 1999.

[9] E.A. Islankina, E.S. Kutsenko, P.B. Rudnik, A.E. Shadrin, Innovation clusters - leaders in world-class investment attractiveness: teaching materials, Moscow: HSE, 2017.

[10] V.L. Abashkin, S.V. Artemov, M.A. Gershman et al., Pilot Innovative Territorial Clusters in the Russian Federation, Moscow: National Research University Higher School of Economics, p. 41, 2015.

[11] V. L. Abashkin, A. D. Boyarov, E. S. Kutsenko, "Cluster policy in Russia: from theory to practice", Forsyth, Vol. 6, No. 3, p. 16-27, 2012.

[12] S. C. Savzikhanova, Development of cluster forms of organization of the innovative educational environment of the macroregion based on network information technologies: concept, models, methods, tools, Diss. Doct. econ. sciences. Makhachkala, 2017, 317 p. 